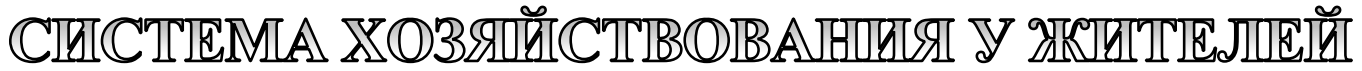

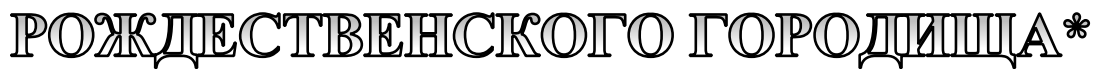

Н.Б. Крыласова, Пермский федеральный исследовательский центр УрО РАН

На Рождественском археологическом комплексе, принадлежащем к числу наиболее изученных средневековых объектов в Пермском крае, имеются свидетельства существования комплексного хозяйства, включающего все отрасли, развитые в этот период на указанной территории. Однако данные о планировке городища, полученные в последнее десятилетие, свидетельствуют о его очень плотной застройке, в связи с чем приобретает актуальность постановка вопросов об особенностях хранения продуктовых запасов, корма для скота, а также о месте содержания домашних животных в зимний период. В статье обобщаются данные археологических и естественно-научных исследований памятника, намечаются задачи для дальнейшего изучения.

Ключевые слова: Пермское Предуралье, эпоха средневековья, ломоватовская культура, родановская культура, хозяйство, Рождественский археологический комплекс.

Одним из наиболее изученных средневековых объектов в Пермском крае является Рождественский археологический комплекс на р. Обва в Карагайском районе. Он включает Филипповское (малое) и Рождественское (большое) городища, неукрепленный посад, мусульманский домонгольский некрополь и языческий могильник [4, с. 6]. На Рождественском городище с посадом вскрыто около 4,5 тыс. кв. м, на языческом могильнике почти 2 тыс. кв. м, исследовано 363 погребения X-XI вв., в меньшей степени раскопкам подвергались Филипповское городище и мусульманский могильник.

За период многолетних исследований здесь собрано значительное количество данных, позволяющих судить о системе хозяйствования и жизнеобеспечении.
Археологические материалы в последние годы активно дополняются результатами естественно-научных исследований. Однако неполнота археологических источников оставляет множество вопросов, решения которых пока не найдено. Но даже постановка этих вопросов имеет важное значение для выработки стратегии дальнейших исследований.

Рождественское городище интерпретируется как торгово-ремесленная фактория Волжской Булгарии, известная по арабским письменным источникам как городок Афкула. Городище не имело сельскохозяйственной округи - в ближайших окрестностях не известно средневековых памятников, за исключением пары невыразительных селищ. Оно находилось в глубине территории в 65 км по р. Обве

\footnotetext{
* Статья подготовлена при поддержке Российского фонда фундаментальных исследований (РФФИ), проект №17-46-590780 «Хозяйственно-культурный облик средневекового Предуралья (комплексное исследование)».
} 
от главной транспортной артерии p. Камы. Население городища составляли носители местной финно-угорской культуры, выходцы из Волжской Булгарии, в меньшей степени - ремесленники и торговцы с соседних финно-угорских земель, и, возможно, с территории Руси. Основным занятием населения являлось ремесло. На городище изучены мастерские различного назначения - металлургические, гончарные, косторезные и пр. Даже в жилищах обнаруживаются следы ремесленной деятельности (кузнечного, литейного, кожевенного производства).

Несмотря на выраженную ремесленную специализацию, жителям городища необходимо было обеспечивать себя продуктами питания и сырьем для домашнего производства. Даже при отсутствии сельскохозяйственной округи не исключено, что часть продуктов получали путем торговли с местным финно-угорским населением, для которого, собственно, предназначалась подавляющая часть ремесленной продукции. Но на городище и сопровождавшем его языческом могильнике собрано достаточно данных, свидетельствующих о существовании здесь комплексного хозяйства, включающего все основные направления (земледелие, животноводство, охоту, рыболовство, собирательство, бортничество). Наиболее наглядно демонстрируют, какие отрасли хозяйства обладали особой значимостью для жителей Рождественского городища в X-XI вв., наборы орудий, сопровождавшие отдельные мужские захоронения на могильнике, выделяющиеся «богатством» погребального инвентаря. В них представлены орудия всех основных хозяйственных занятий населения (земледелие, охота, рыболовство, даже отчасти бортничество, так как присутствующие в комплексах деревообрабатывающие орудия могли применяться и для изготовления бортей), за исключением скотоводства, где практически не использовалось каких-либо специализированных орудий. Предположительно, эти комплексы могли принадле- жать главам семейств, несущих ответственность за умерших членов семьи, для которых они должны были в «загробном мире» построить дом, обустроить быт и наладить привычное хозяйство [9, с. 26].

Земледелие - самая трудозатратная отрасль хозяйства. В эпоху средневековья преобладающей являлась подсечно-огневая система земледелия, которая заключалась в выжиге леса на отдельных участках и посеве семян непосредственно в золу без какой-либо предварительной обработки поля. Основным орудием земледельцев на этом этапе являлся топор. Возможно, поэтому именно топор выступает на Рождественском могильнике в качестве основного «статусного» предмета, сопровождавшего элитные мужские погребения. Первые 1-2 года поле давало большие урожаи, затем начинало зарастать сорняками, новый посев без вспашки становился невозможным [12, c. 32-35]. Для обработки полей до конца ХІ в. использовали мотыги с железными наконечниками (они представлены в большинстве упомянутых комплексов в мужских погребениях), после - деревянные рала с железными наконечниками (подобные известны в материалах городища). Поле использовалось до 5 лет, а затем забрасывалось на 20-30 лет до полной регенерации лесной структуры.

Подсека не была только сельскохозяйственной практикой, а являлась системой природопользования. Подсечно-огневое земледелие стало одним из основных антропогенных факторов, повлиявших на изменение природного ландшафта в древности [12, с. 35]. В частности, первые палинологические исследования, проведенные на Рождественском городище, показали, что до его возведения на окружающей территории были распространены луговые сообщества и липово-темнохвойные леса (сначала с елью, а позднее и пихтово-еловые); роль сосны в древостое лесов была незначительна. С началом функционирования городища в темнохвойных формациях возросла роль березы как следствие 
вырубки хвойных пород [10, с. 21]. Вырубка, безусловно, осуществлялась и с целью получения строительного материала, но, в значительной степени, и для сжигания под посевы. Как показали палинологические исследования, в окрестностях городища существовали обрабатываемые земли, где выращивали хлебные злаки, о чем свидетельствует наличие пыльцевых зерен группы культурных злаков (это подтверждается и многочисленными находками в культурном слое зерновок разнообразных культурных злаков) и сегетальных сорняков (например василек синий - Centaurea cianus L.). Сейчас в окрестностях городища преобладают вторичные сосновые леса, возникшие на месте коренных лесных формаций [10, с. 21].

Для Рождественского городища имеются определения зерна, как выделенного визуально в скоплениях, так и полученного методом флотации (промывки культурного слоя). Четыре пробы из раскопок 1990-х гг. показали, что здесь преобладали ячмень обыкновенный $(34,4 \%)$, овес посевной $(23,6 \%)$, полба-двузернянка $(22,1 \%)$ и мягкая пшеница $(18,5 \%)$, ржи встречено относительно немного $(1,4 \%)$ (определение В.В. Туганаева) [12, с. 38]. Первые результаты анализа проб, полученных более объективным методом флотации, показали, что преобладающими являлись зерна ячменя и пшениц, в небольшой примеси встречаются зерна ржи и овса [13, с. 27]. Значимым результатом стало выделение в пробах семян технической культуры - конопли, волокна которой использовались в качестве сырья для текстильного производства, изготовления пеньковых веревок, а семена - для производства масла, которое употреблялось в пищу и применялось для технических нужд [13, с. 28].

В период мотыжного земледелия его продуктивность была невысока. Зерно хранили в керамической таре в ямах-кладовках, в пищу использовали ограниченно - в виде крупы при приготовлении похлебок и каш [5, с. 20-21]. С распространением пашенного земледелия его про- дуктивность возросла. Для помола зерна стали использовать жернова, обломки которых часто встречаются на городище. Вероятно, расширился ассортимент блюд, приготавливаемых из зерна (в частности, появился хлеб). В связи с возросшей продуктивностью земледелия встал вопрос о местах хранения запасов зерна.

Результаты раскопок Рождественского городища, в особенности последнего десятилетия, показывают, что оно имело очень плотную застройку, в целом характерную для средневековых городков. В наиболее изученной восточной части площадки городища выделяются ряды жилищ, образующие улицы, радиально расходящиеся от наиболее высокой точки у вала к береговому обрыву р. Обва. Жилища располагались на расстоянии 1-2 м друг от друга, пространства между ними (вероятно, крытые) использовались в качестве подсобных хозяйственных помещений. Между рядами жилищ оставался проход (проезд?) шириной 3-4 м [6; 7, с. 559-560]. При такой плотности застройки никакими хозяйственными дворами жилища не сопровождались.

В археологии Пермского края утвердилось представление о том, что в период родановской археологической культуры получили распространение ямы-хранилища, вынесенные за пределы жилищ [11, с. 264-266], и, в частности, зерновые ямы [11, с. 279]. Такие ямы, подробно охарактеризованные А.Н. Сарапуловым [12, с. 93-97], на Рождественском городище пока не выявлены. Поэтому открытым остается вопрос о том, обладали ли домохозяйства собственными зернохранилищами, или на данном городище существовало какое-то централизованное хранилище зерновых запасов. Пока же имеющиеся данные свидетельствуют о том, что внутри жилищ в ямах-кладовках, которые обычно устраивались под печью, зерно хранилось хорошо очищенным, подготовленным к употреблению (крупа) [13, с. 28]. Это дает основание считать, что ямы-кладовки в жилищах предназначались исключительно 
для хранения продуктов, необходимых для повседневного приготовления пищи.

Вторым видом производящего хозяйства является жсивотноводство. Главное свидетельство его развития на Рождественском городище - присутствие в культурном слое многочисленных костей животных (к примеру, в 2008 г. на раскопе площадью 103 кв. м собрано свыше 12 тыс. костей). На всех изученных участках памятника кости домашних существенно преобладали над костями диких животных. В составе стада первое место по численности занимал крупный рогатый скот (47-55\% на разных раскопах), второе - лошадь (24-46\%), третье - мелкий рогатый скот (6-21\%). Доля свиньи весьма незначительна (до 1\%) [1, с. 33]. На основе перекрестного анализа различных фактов выдвинуто предположение, что до XII в. молоко в пищу практически не употреблялось [5, с. 19-20]. И поскольку постоянно доить животных не требовалось, в летний период их могли выпасать на значительном удалении от жилья, например, на заливных лугах в пойме Обвы.

Но открытым остается вопрос о месте содержания скота в зимний период. Наиболее достоверным представляется предположение о том, что для содержания скота могли использовать переднюю часть домов, отделенную перегородкой от жилого помещения. Но пока нет данных, подтверждающих это. Для решения этого вопроса необходимо проведение дальнейших раскопок и отбор проб для естественно-научных исследований (в частности, свидетельством длительного присутствия скота в определенном месте может являться повышенное содержание азота в культурном слое). Не ясным остается и вопрос о местах хранения кормов в зимний период. Как известно, при топке жилищ «почерному» (т.е. очагами и печами без дымоходов), потолок в них не устраивался, следовательно, не было и чердаков, которые могли служить сеновалами.

Из отраслей присваивающего хозяйства первоочередное значение имела охота.
Согласно данным, полученным палеозоологами, кости промысловых животных на разных участках городища составляют от 6 до 33\%. Из промысловых млекопитающих наиболее многочисленны остатки лося, бобра и северного оленя; заметную роль в промысле играл и заяц-беляк. Доля остальных млекопитающих (среди которых представлены лисица, куница, соболь, выдра, белка, косуля, кабан, медведь, волк, барсук, росомаха) в промысле была незначительной [1, с. 34, табл.1].

Спектр добычи диких зверей был довольно широк, но на поселение приносили, в основном, туши лося, северного оленя и бобра $[1$, с. 35$]$. Дело в том, что особое значение в этот период имела пушная охота, пушнина принадлежала к числу основных товаров, экспортируемых из Пермского Предуралья. Пушные животные в пищу не употреблялись, свежевались непосредственно в лесу, их кости на городище встречаются выборочно. К примеру, широко распространены амулеты из нижней челюсти куницы или лисы, из зубов и костей других пушных животных, игольники и манки из бедренных костей куницы и пр. Исключение составляет бобр, у которого использовали не только мех, но и ценное вещество «бобровую струю», и мясо. Из кожи с хвоста бобра, обладающей необычной ячеистой структурой поверхности, делали поясные кошельки (подобные известны на Рождественском могильнике). Поэтому не случайно кости бобра в значительном количестве присутствуют на городище.

Как отмечают палеозоологи, во все периоды функционирования городища промысел млекопитающих преобладал над добычей пернатой дичи и рыболовством (птицам принадлежит 1-3\% костных остатков, а рыбам менее $1 \%[1$, с. 32,35$]$. Данные по рыболовству соотносятся и с находками на городище деталей рыболовных снастей - в основном здесь встречаются рыболовные крючки малых и средних размеров, использовавшиеся для ловли рыбы на удочку, да и то в незначитель- 
ном количестве. Небольшим количеством экземпляров представлены железные и костяные одношипные наконечники стрел, применявшихся для лучения рыбы. Но на могильнике в упомянутых комплексах хозяйственных орудий, как правило, присутствуют крупные массивные рыболовные крючки, предназначавшиеся для самоловной снасти [3, с. 46], что может служить отражением представлений о значимости рыболовства как отрасли хозяйства, несмотря на то, что на данном конкретном городище оно не играло особой роли.

О занятии жителей Пермского Предуралья бортничеством свидетельствуют упоминания в письменных источниках, где указывается на регулярное употребление меда в пищу. Мед и воск перечисляются в списках товаров из Волжской Болгарии, куда он мог поставляться, в частности, из Предуралья. Как отмечалось выше, в окрестностях Рождественского городища произрастали липово-темнохвойные леса. Наличие широколиственных растений, особенно липы и дуба, благоприятствует распространению пчел, которые, как известно, живут в симбиозе с этими растениями. В период средневековья, когда возросла потребность в меде в связи с включением Предуралья в систему евразийской Восточной торговли, его добыча обрела характер промысла, и в Предуралье начало развиваться бортничество. А.М. Белавиным проанализированы специальные инструменты и предметы снаряжения бортников, из них в материалах Рождественского городища выделены древолазные шипы, медорезные ножи, а также многочисленные деревообрабатывающие инструменты, которые могли использоваться для изготовления бортей (втульчатые топоры-пешни, тесла, долота и пр.) [2].

Пока немного данных имеется о собирательстве, хотя, без сомнения, люди широко использовали в пищу дикоросы. При исследованиях проб, отобранных методом флотации, выделены пока только косточки малины [Трофимова, с. 26], без сомнения, ассортимент дикоросов расширится за счет дальнейших палеоботанических исследований. В 2018 г. была обнаружена скорлупа ореха-лещины.

Таким образом, у жителей Рождественского городища наряду с ремесленной деятельностью существовала комплексная система хозяйства, направленная на жизнеобеспечение. Это подтверждается составом орудий в мужских погребениях могильника, где наряду с ремесленными инструментами обязательно присутствуют основные виды хозяйственных орудий. Некоторые отрасли хозяйства (к примеру, пушная охота, бортничество), были частью товарной деятельности, ориентированной, в основном, на внешний рынок, в них предполагается наличие специалистов-промысловиков. Задачами дальнейших исследований являются вопросы, связанные с продуктивностью земледелия и способностью обеспечить необходимую потребность населения в зерне, с особенностями уборки урожая и его хранения; в области животноводства - вопросы о направлениях (мясное, молочное или комплексное), об использовании животных в хозяйственных целях (например, лошадей и быков как транспортных животных), о породах домашних животных, особенностях зимнего содержания скота и о заготовке кормов [8].

\section{Библиографический список}

1. Бачура О.П., Гасилин В.В., Косинщев П.А. Археозоологические материалы из Рождественского городища (планиграфический анализ) // Вестник Пермского научного центра УрО РАН. - 2016. № 3. - C. 30-35.

2. Белавин А.M. О «медовой составляющей» в палеоэкономике Пермского Предуралья // Формирование и взаимодействие уральских народов в изменяющейся этнокультурной среде Евразии: проблемы изучения и историография. - Уфа: КИТАП, 2007. - С. 222-230.

3. Белавин А.М. Рыбная ловля в Прикамье в древности и средние века // Вестник Пермского научного центра УрО РАН. - 2016. - № 3. - С. 42-47. 
4. Белавин А.М., Крыласова Н.Б. Древняя Афкула: археологический комплекс у с. Рождественск. Пермь: ПФ ИИиА УрО РАН, 2008. - 603 с.

5. Крыласова Н.Б. Археология повседневности: материальная культура средневекового Предуралья. Пермь: ПГПУ, 2007. -352 с.

6. Крыласова Н.Б. Особенности средневекового домостроительства на территории Пермского края // Вестник Пермского научного центра УрО РАН. - 2016. - № 3. - С. 63-76.

7. Крыласова Н.Б. Жилища и планировка Рождественского городища: к вопросу об особенностях средневекового домостроительства у финно-угорского населения Пермского Предуралья // V (XXI) Всероссийский археологический съезд: сб. науч. тр. - Барнаул: АлтГУ, 2017. - С. 559-560.

8. Крыласова Н.Б. Хозяйство и система жизнеобеспечения средневекового населения Предуралья (проблемы реконструкции) // Современные решения актуальных проблем евразийской археологии: сб. науч. ст. / отв. ред. А.А. Тишкин. - Барнаул: изд-во Алт. ун-та, 2018. - Вып. 2. - С. 221-225.

9. Крыласова Н.Б., Белавин А.М. Комплексы орудий в мужских захоронениях ломоватовской культуры как отражение основных хозяйственных и производственных занятий населения // Magistra Vitae: электронный журнал по историческим наукам и археологии. - 2015. - № 6 (361). - С. 16-27.

10. Лаптева Е.Г., Крыласова Н.Б., Сарапулов А.Н. Результаты палинологического изучения отложений археологического памятника Рождественское городище (2015 год) // Вестник Пермского научного центра УрО РАН. - 2016. - № 3. - С. 15-22.

11. Оборин B.A. Коми-пермяки // Финно-угры Поволжья и Приуралья в средние века. - Ижевск: УдИИЯЛ УрО РАН, МарНИИ, 1999. - С. 255-298.

12. Сарапулов А.Н. Средневековое земледелие Пермского Предуралья по археологическим данным. Пермь: ПГГПУ, 2015. - 170 с.

13. Трофимова С.С., Крыласова Н.Б., Сарапулов А.Н. Археоботанические исследования средневекового Рождественского городища (Пермский край) // Вестник Пермского научного центра УрО РАН. 2016. - № 3. - С. 23-29.

\title{
THE MANAGEMENT SYSTEM OF THE RESIDENTS OF ROZHDESTVENSKOE SETTLEMENT
}

\author{
N.B. Krylasova \\ Perm Federal Research Center UB RAS
}

At the space of the archaeological complex Rozhdestvensky, one of the most studied medieval objects in the Perm region, there is some evidence of the existence of mixed farming including all the industries developed during this period on this territory. However, the data on the layout of the settlement obtained in the last decade indicate its building density, and therefore it becomes relevant to raise the questions about storage characteristics of food supplies, cattle feed and pet housing in winter. The article summarizes the data of archaeological and natural scientific studies of the monument and outlines the tasks for further research.

Keywords: Perm Cis-Ural region, the Middle Ages, the Lomovatovskaya culture, the Rodanovskaya culture, farming, archaeological complex Rozhdestvensky.

\section{Сведения об авторе}

Крыласова Наталья Борисовна, доктор исторических наук, главный научный сотрудник отдела истории, археологии и этнографии, Пермский федеральный исследовательский центр УрО РАН (ПФИЦ УрО РАН), 614990, г. Пермь, ул. Ленина, 13А; e-mail: n.krylasova @ mail.ru 